The Egyptian Journal of Biochemistry \& Molecular Biology VOL 36(N.1\&2) 35-48 December. 2018

\title{
Insulin-like Growth Factor 2 Binding Protein 2 Gene Polymorphism in Egyptian Patients with Type 2 Diabetes
}

\author{
Mohammed A. Hajar( ${ }^{(1)}$, Nagwan A. Sabek ${ }^{(1) *}$, Amany Y. El-kazaz ${ }^{(1)}$ \\ Fathalla M. Hassan (1), Abdelraouf M. Eldeib ${ }^{(2)}$ \\ ${ }^{1}$ Medical Biochemistry and Molecular Biology, ${ }^{2}$ Internal Medicine \\ Departments, Faculty of Medicine, Suez Canal University, Round \\ Road, Ismailia, Egypt
}

\section{Received 22/4/2018- Accepted 13/5/2018}

\begin{abstract}
Genome-wide association studies (GWAS) identified novel genes associated with type 2 diabetes mellitus (T2DM) which have been replicated in different ethnic populations and yielded inconsistent results. The insulin-like growth factor mRNA-2 binding protein 2 $(I G F 2 B P 2)$ is highly expressed in pancreatic islets, which play roles in normal embryonic growth and development. Our study aimed to replicate the association between insulin growth factor 2 mRNA binding protein 2 (IGF2BP2) gene (rs4402960) variant and T2DM in Egyptian diabetic patients resident in Ismailia city. The study included 152 subjects (76 unrelated T2DM patients and 76 control subjects) who were genotyped by polymerase chain reaction-restriction fragment length polymorphism technique (PCR- RFLP). Age, sex, blood pressure, BMI and Waist Circumference were recorded, and blood glucose, serum triglyceride, total cholesterol (TC), low-density lipoprotein-cholesterol (LDL-C), high-density lipoprotein-cholesterol (HDL-C) and homeostatic model assessment (HOMA) indices were determined. Fasting serum insulin and IGF2BP2 protein levels were analyzed by ELISA. For rs440960 variant of IGF2BP2 gene, risk allele $\mathrm{T}$ frequency was associated with T2DM [OR $(95 \% \mathrm{CI})=1.82$ (1.14- 2.93), $\mathrm{P}=0.012$ ]. The frequency of $\mathrm{T} / \mathrm{T}$ genotype versus $(\mathrm{GG}+\mathrm{G} / \mathrm{T})$ genotypes was significantly higher in T2DM patients compared to controls $(22.4 \%$ vs. $77.6 \%$ and $5.3 \%$ vs. $94.7 \%$, respectively), $(\mathrm{P}=0.002)$. This association remained significant under additive $(\mathrm{P}=0.003)$ and co-dominant $(\mathrm{P}=0.009)$ genetic models. From this study, it could be concluded that IGF2BP2 rs4402960 polymorphism was found to be significantly associated with the
\end{abstract}

* Carrespandence Author (nagwan_yasser@yahoa.com) 
increased risk of T2DM.

Keywords: Type 2 diabetes mellitus, Single nucleotide polymorphism, IGF2BP2.

\section{INTRODUCTION}

Diabetes mellitus is a worldwide medical issue with a an enormous effect on morbidity and premature mortality worldwide. The estimated global prevalence of diabetes among adults (aged 20-79 years old) will be $8.8 \%$, influencing 425 million adults in 2017 and will increment to $9.9 \%$, and 629 million adults by the 2045 (International Diabetes Federation, 2017).

T2DM is a disease characterized by high blood glucose levels as a result of a pancreatic $\beta$-cell dysfunction, impaired insulin secretion and insulin resistance and is caused by the perplexing interaction between genetic, epigenetic, and environmental factors. T2DM is a complex metabolic syndrome with a strong genetic components play a role in the pathogenesis of T2DM (Ding et al., 2015).

The IGF2BP2 is RNA-binding protein in humans that is encoded by the IGF2BP2 gene (Hafner et al., 2010) and implicated in mRNA localization, stability, and translational control (Ye et al., 2016). IGF2BP2 binds to and regulates the translation of a set of mRNA including IGF2, which thusly is engaged with the improvement of insulin function (Boudoukha et al., 2010; Li et al., 2013).

The IGF2BP2 gene variants are arranged on the chromosome (3q27.2). The intron 2 is the location of (rs44020960) and (rs1470579) SNPs, which have been observed to be related to an increased risk for T2DM (Chistiakov et al., 2012). IGF2BP2 has seen to be identified with decreased insulin secretion, which assumes a part of T2DM. IGF2BP2 gene variant may end up impacting the levels of IGF2 in $\beta$ cells. IGF2 overexpression induces $\beta$-cell dysfunction and increases $\beta$ cell susceptibility to damage (Casellas et al., 2015). In this study, we intended to evaluate the presence of $I G F 2 B P 2$ gene polymorphism and to assess whether it associated with T2DM risk in Egyptian patients resident in Ismailia city.

\section{MATERIALS AND METHODS}

This case-control study included 152 subjects, (76 unrelated T2DM patients and 76 healthy control subjects). The T2DM patients were recruited from the diabetes clinic at Suez Canal University Hospital, 
based on their medical record and fulfilling the diagnostic criteria of American Diabetes Association that specifies fasting plasma glucose (FPG) $\geq 126 \mathrm{mg} / \mathrm{dl}$ or $2 \mathrm{~h}$ postprandial plasma glucose $(\mathrm{PPG}) \geq 200$ $\mathrm{mg} / \mathrm{dl}$ (American Diabetes Association,2017). Full medical history and anthropometric measurements were recorded. Patients with type 1 diabetes mellitus, ischemic heart disease, kidney or liver diseases and pregnant women were excluded from this study. Dyslipidemia was diagnosed if fasting total serum cholesterol $(\geq 200 \mathrm{mg} / \mathrm{dl}$ ), (LDLcholesterol $\geq 130 \mathrm{mg} / \mathrm{dl})$, fasting serum triglycerides $(\geq 150 \mathrm{mg} / \mathrm{dl})$ or HDL-C $(<40 \mathrm{mg} / \mathrm{dl})$ in men or $(<50 \mathrm{mg} / \mathrm{dl}$ in women $)$ or treated by statins (National Cholesterol Education Program (NCEP), 2002). Patients were considered obese when BMI was $>25$ (the weight in kilograms divided by the square of the height in meters) (Yamada et al., 2002). Informed consent was obtained from all subjects and the study protocol was approved by the Ethics Committee of Faculty of Medicine in Suez Canal University.

Biochemical Measurements Venous blood samples were collected from all subjects after overnight fasting (fasting plasma glucose was after 8 hours and lipid profile was after 12 hours). Fasting plasma glucose and lipid profile levels; total cholesterol (TC), triglycerides (TG), high-density lipoprotein cholesterol (HDL-C) and low-density lipoprotein cholesterol (LDL-C) were determined according to manufacturer's protocol (Biosystem S.A, Spain) and assayed on Novaspec II Spectrometer ( Biochrom, UK). Fasting serum insulin (DRG Insulin ELISA kit, DRG International, Inc., USA) and IGF2BP2 protein (IGF2BP2 ELISA Kit, Cusabio Biotech Co., Ltd, China) levels were determined according to

manufacturer's protocol and measured by using microplate reader (Stat Fax 2100, Awareness Technology, Inc., USA). Homeostasis assessment model assay (HOMA) indices were calculated as well. The following equations were used: HOMA-IR = (fasting insulin $(\mu \mathrm{U} / \mathrm{ml}) \times$ Fasting blood glucose $(\mathrm{mmol} / \mathrm{l}) / 22.5$, HOMA- $\beta \%=(20 \mathrm{x}$ fasting insulin $(\mu \mathrm{U} / \mathrm{ml}))$ / Fasting blood glucose (mmol/l) (Matthews et al.,1985). Genotyping of IGF2BP2 SNP(rs4402960)

Genomic DNA was purified from whole blood by using a QIAamp DNA Blood Mini Kit (Qiagen, UK) according to manufacturer's protocol. Genotypes for the IGF2BP2 rs4402960 polymorphism were analyzed using a polymerase chain reaction-restriction fragment length polymorphism (PCR-RFLP) assay. All primers designed by 
Biosearch Technologies Inc (USA). The primers sequence were Forward5'-AGACCAGCCTTGGCAATGTAGTG-3' and reverse 5'CTAAAGCACTGAGAGAAACAGCCCT-3'. DNA was initially denatured at $95^{\circ} \mathrm{C}$ for $5 \mathrm{~min}$ prior to amplification. then 30 cycles, consisting of 2 min denaturation at $95^{\circ} \mathrm{C}, 45 \mathrm{sec}$ annealing at $62^{\circ} \mathrm{C}$, and $1 \mathrm{~min}$ extension at $72{ }^{\circ} \mathrm{C}$ and the final extension for $1 \mathrm{~min}$ at $72{ }^{\circ} \mathrm{C}$. Restriction digestion was performed in a total volume of $10 \mu \mathrm{l}$ amplicons, $1 \mu \mathrm{l} \mathrm{NE}$ buffer and 8 units of Mbo II enzyme (New England Bio-labs, Beverly, Mass, USA). Samples were then incubated for $5 \mathrm{hrs}$ at $37{ }^{\circ} \mathrm{C}$ and the digested PCR products were separated by $2.0 \%$ agarose gel electrophoresis. Thus, the following genotypes were identified by bands of the following sizes; GG (Homozygous): 2 bands (282 bp and $157 \mathrm{bp}$ ), GT (Heterozygous): 3 bands (439 bp, 282 bp and $157 \mathrm{bp}$ ) and TT (variant Homozygote): one band at $439 \mathrm{bp}$ (figure 12), (Huang et al., 2010).

Statistical Analysis Statistical analyses were performed with SPSS software version 22.0 for Windows (Chicago, IL, USA). Data were expressed as mean \pm SD for continuous variables and as percentages of the total for categorical variables. Intergroup significance was assessed by Student's t-test for continuous variables and Chi-square $(\chi 2)$ test for categorical variables.

The Hardy-Weinberg equilibrium was estimated by $\chi^{2}$ test. $\chi^{2}$ was used to test the difference in alleles and genotypes frequency between groups.

\section{RESULTS}

\section{Clinical and biochemical characteristics of the studied subjects:}

The clinical and biochemical characteristics of studied subjects were summarized in Table (1). T2DM patients had significantly higher BMI, fasting plasma glucose, Triglycerides, Total Cholesterol, HOMA-IR and IGF2BP2 protein and significantly lower HOMA- $\beta \%$ and HOMA-S\% compared to healthy controls $(\mathrm{P}<0.05)$.

\section{Genotyping analysis and allelic frequencies:}

Diabetic patients and controls were genotyped for IGF2BP2 gene (rs4402960) polymorphism (figure 1). The genotypic distributions of (rs4402960) SNP were in agreement with Hardy-Weinberg equilibrium $(\mathrm{P}>0.05)$. The risk $\mathrm{T}$ allele frequency was significantly higher in T2DM patients than in controls (43.4\% vs. $29.6 \%)$ [OR $(95 \% \mathrm{CI})=1.82(1.14-2.93), \mathrm{P}=0.012]$. The frequency of $\mathrm{T} / \mathrm{T}$ 
genotype versus $(\mathrm{GG}+\mathrm{G} / \mathrm{T})$ genotypes was significantly higher in T2DM patients compared to controls $(22.4 \%$ vs. $77.6 \%$ and $5.3 \%$ vs. $94.7 \%$, respectively), $(\mathrm{P}=0.002)$. Distribution of IGF2BP2 (rs4402960) variant genotypes and alleles in T2DM patients and controls and their association analyses under additive (TT vs. GG), dominant (GG vs. GT+TT), recessive (TT vs. GG+GT) and codominant (GG vs. GT vs. TT) genetic models also were summarized in Tables (2 and 3).

Table (4) shown the effect of the IGF2BP2 variant (rs4402960) genotypes on risk factors of T2DM in patients group and indicated that fasting plasma glucose level and HOMA- $\beta \%$ were statistically significant higher $(\mathrm{P}<0.05)$ in T2DM patients with $(\mathrm{GT}+\mathrm{TT})$ genotype compared to T2DM patients with (GG) genotype, while no statistically significant difference in T2DM patients regarding other measured risk factors .

Table 1. Clinical and Biochemical characteristics of T2DM patients and healthy controls

\begin{tabular}{|c|c|c|c|}
\hline Variable & Patient $(n=76)$ & Control (n=76) & P value \\
\hline n (male/female) & $76(38 / 38)$ & $76(39 / 37)$ & - \\
\hline Age (Years) & $56.51 \pm 7.20$ & $54.47 \pm 7.70$ & 0.094 \\
\hline SBP $(\mathbf{m m H g})$ & $133.07 \pm 18.67$ & $122.37 \pm 14.32$ & ${ }^{*} 0.0001$ \\
\hline DBP (mmHg) & $93.55 \pm 13.66$ & $82.89 \pm 8.46$ & $0.0001^{*}$ \\
\hline BMI (kg/m2) & $31.78 \pm 5.71$ & $29.76 \pm 6.41$ & $0.042^{*}$ \\
\hline Waist Circumference(cm) & $109.82 \pm 11.76$ & $106.26 \pm 15.63$ & 0.116 \\
\hline Fasting plasma glucose (mg/dl) & $206.58 \pm 83.91$ & $92.84 \pm 12.71$ & $0.0001^{*}$ \\
\hline Total Cholesterol (mg/dl) & $188.49 \pm 56.817$ & $168.03 \pm 51.87$ & $0.022^{*}$ \\
\hline Triglyceride (mg/dl) & $181.28 \pm 93.77$ & $121.24 \pm 58.98$ & $0.0001^{*}$ \\
\hline HDL-C (mg/dl) & $42.58 \pm 10.73$ & $45.63 \pm 12.18$ & 0.103 \\
\hline LDL-C $(\mathrm{mg} / \mathrm{dl})$ & $109.55 \pm 53.25$ & $98.18 \pm 46.80$ & 0.164 \\
\hline Fasting serum insulin $(\mu \mathrm{IU} / \mathrm{ml})$ & $12.22 \pm 9.70$ & $11.98 \pm 10.30$ & 0.879 \\
\hline HOMA- $\beta \%$ & $36.99 \pm 31.30$ & $117.61 \pm 61.08$ & $0.0001^{*}$ \\
\hline HOMA-S\% & $73.96 \pm 54.28$ & $103.82 \pm 65.75$ & $0.003^{*}$ \\
\hline HOMA-IR & $2.66 \pm 3.54$ & $1.54 \pm 1.29$ & $0.010^{*}$ \\
\hline IGF2BP2 PROTEIN (pg/ml) & $248.79 \pm 88.41$ & $173.29 \pm 74.64$ & $0.0001^{*}$ \\
\hline
\end{tabular}

Comparisons were performed by independent Samples t-test; data are mean $\pm S D$. ${ }^{*} P<0.05$ is statistically significant,$n$ : number of individuals, SBP : Systolic Blood Pressure, DBP: Diastolic Blood Pressure, BMI: Body Mass Index, HDL-C: High Density Lipoprotein-Cholesterol ,LDL-C: Low Density Lipoprotein-Cholesterol, HOMA-B \% : Homeostatic model assessment of B-cell function, HOMA-S\%: Homeostatic model assessment of insulin sensitivity, HOMA-IR; Homeostatic model assessment of insulin resistance, IGF2BP2: insulin growth factor 2 mRNA binding protein 2. 
Table 2. Genotypes distribution and allele frequencies of the IGF2BP2 gene variant (rs4402960) in T2DM patients and Controls

\begin{tabular}{|c|c|c|c|c|c|}
\hline & $\begin{array}{c}\text { Controls } \\
n=76\end{array}$ & $\begin{array}{c}\text { Diabetic } \\
\text { Patients } \\
n=76\end{array}$ & OR $(95 \%$ CI $)$ & $\chi^{2}$ & $\begin{array}{c}\mathbf{P} \\
\text { value }\end{array}$ \\
\hline \multicolumn{6}{|l|}{ Genotype } \\
\hline G/G & $35(46.0 \%)^{a}$ & $27(35.5 \%)$ & & & \\
\hline G/T & $37(48.7 \%)$ & $32(42.1 \%)$ & $1.12(0.56-2.23)^{b}$ & 0.1055 & 0.745 \\
\hline$T / T$ & $4(5.3 \%)$ & $17(22.4 \%)$ & $5.51(1.66-18.28)^{c}$ & 8.8106 & 0.003* \\
\hline \multicolumn{6}{|l|}{ Allele } \\
\hline G & $\begin{array}{c}107(70.4 \\
\%)\end{array}$ & $86(56.6 \%)$ & \multirow[t]{2}{*}{$1.82(1.14 \text { to } 2.93)^{d}$} & \multirow[t]{2}{*}{6.2579} & \multirow[t]{2}{*}{$0.012^{*}$} \\
\hline $\mathbf{T}$ & $45(29.6 \%)$ & $66(43.4 \%)$ & & & \\
\hline
\end{tabular}

Comparisons were performed by the chi-square test $\left(\chi^{2}\right), C I$ : confidence interval, OR: odds ratio, a: Data is represented as number and \%,b: GT vs.GG, c: TT vs. $G G, d: T v s . G, * P<0.05$ is statistically significant.

Table 3. Genetic models of the IGF2BP2 gene variant (rs4402960) in T2DM patients and Controls

\begin{tabular}{|c|c|c|c|c|}
\hline Genetic Models & Controls & $\begin{array}{l}\text { Diabetic } \\
\text { Patients }\end{array}$ & OR $(95 \% \mathrm{CI})$ & $P$ value \\
\hline Additive & & & \multirow{3}{*}{$5.51(1.66-18.30)$} & \multirow{3}{*}{$0.003 *$} \\
\hline GG & $\begin{array}{c}35 \\
(46.0 \%)^{a}\end{array}$ & $27(35.5 \%)$ & & \\
\hline TT & $4(5.3 \%)$ & $17(22.4 \%)$ & & \\
\hline Recessive & & & \multirow{3}{*}{$5.18(1.66-16.25)$} & \multirow{3}{*}{$0.002^{*}$} \\
\hline TT & $4(5.3 \%)$ & $17(22.4 \%)$ & & \\
\hline GG+GT & $72(94.7 \%)$ & $59(77.6 \%)$ & & \\
\hline Dominant & & & \multirow{3}{*}{$1.55(0.81-2.97)$} & \multirow{3}{*}{0.188} \\
\hline GG & $35(46.0 \%)$ & $27(35.5 \%)$ & & \\
\hline GT+TT & $41(54.0 \%)$ & $49(64.5 \%)$ & & \\
\hline Co-dominant & & & \multirow{4}{*}{$4.91(1.50-16.11)^{b}$} & \multirow{4}{*}{$0.009 *$} \\
\hline GG & $\begin{array}{c}35 \\
(46.0 \%)^{a}\end{array}$ & $27(35.5 \%)$ & & \\
\hline GT & $\begin{array}{c}37(48.7 \\
\%)\end{array}$ & $32(42.1 \%)$ & & \\
\hline TT & $4(5.3 \%)$ & $17(22.4 \%)$ & & \\
\hline
\end{tabular}

Comparisons were performed by the chi-square test $\left(\chi^{2}\right)$, CI: confidence interval, OR: odds ratio, a: Data is represented as number and \%, b: GT vs.TT, *P<0.05 is statistically significant.

Additive model (TT vs. GG), recessive model (TT vs. $G G+G T)$ ), dominant model ( $G G$ $v s .+G T+T T)$, and co-dominant model (GG vs. GT vs. TT). 
Table 4. Clinical and biochemical measurements among T2DM patients according to the genotype distribution

\begin{tabular}{|c|c|c|c|}
\hline Variables & )VGG (n=2 & ) $9 G T+T T(n=4$ & $\begin{array}{c}\mathbf{P} \\
\text { value }\end{array}$ \\
\hline AGE (Years) & $58.22 \pm 7.55$ & $55.57 \pm 6.90$ & 0.125 \\
\hline $\begin{array}{c}\text { Disease duration } \\
\text { (Years) }\end{array}$ & $7.56 \pm 4.29$ & $6.41 \pm 4.59$ & 0.286 \\
\hline SBP $(\mathbf{m m H g})$ & $134.81 \pm 19.24$ & $132.10 \pm 18.49$ & 0.580 \\
\hline DBP (mmHg) & $95.19 \pm 13.62$ & $92.65 \pm 13.74$ & 0.443 \\
\hline BMI (kg/m2) & $32.72 \pm 4.65$ & $31.27 \pm 6.20$ & 0.291 \\
\hline $\begin{array}{c}\text { Waist } \\
\text { Circumference }(\mathrm{cm}) \\
\end{array}$ & $110.96 \pm 11.02$ & $109.18 \pm 12.22$ & 0.532 \\
\hline $\begin{array}{l}\text { Fasting plasma } \\
\text { glucose }(\mathrm{mg} / \mathrm{dl})\end{array}$ & $179.78 \pm 56.80$ & $221.35 \pm 92.89$ & $0.038 *$ \\
\hline $\begin{array}{c}\text { Total Cholesterol } \\
(\mathrm{mg} / \mathrm{dl})\end{array}$ & $195.85 \pm 58.68$ & $184.43 \pm 55.96$ & 0.405 \\
\hline Triglyceride (mg/dl) & $177.07 \pm 104.92$ & $183.59 \pm 88.10$ & 0.774 \\
\hline HDL-C (mg/dl) & $42.07 \pm 12.20$ & $42.86 \pm 9.96$ & 0.763 \\
\hline LDL-C (mg/dl) & $118.22 \pm 55.27$ & $104.80 \pm 52.11$ & 0.296 \\
\hline $\begin{array}{c}\text { Fasting serum } \\
\text { insulin }(\mu \mathrm{l} \mathrm{U} / \mathrm{ml})\end{array}$ & $12.70 \pm 9.82$ & $11.96 \pm 9.72$ & 0.751 \\
\hline НОМА- $\beta \%$ & $47.3 \pm 42.21$ & $31.36 \pm 21.80$ & $0.033^{*}$ \\
\hline HOMA-S\% & $70.46 \pm 49.45$ & $75.89 \pm 57.16$ & 0.679 \\
\hline HOMA-IR & $1.97 \pm 1.72$ & $3.04 \pm 4.19$ & 0.210 \\
\hline $\begin{array}{c}\text { IGF2BP2 PROTEIN } \\
(\mathrm{pg} / \mathrm{ml})\end{array}$ & $245.00 \pm 82.87$ & $240.90 \pm 85.00$ & 0.840 \\
\hline
\end{tabular}

Comparisons were performed by independent Samples $t$-test; data are mean $\pm S D$. $* P<0.05$ is statistically significant $, n:$ number of individuals, SBP: Systolic Blood Pressure ,DBP: Diastolic Blood Pressure, BMI: Body Mass Index, HDL-C: High Density Lipoprotein-Cholesterol, LDL-C: Low Density Lipoprotein-Cholesterol, HOMA- $\beta \%$ : Homeostatic model assessment of $\beta$-cell function, HOMA-S\%: Homeostatic model assessment of insulin sensitivity, HOMA-IR; Homeostatic model assessment of insulin resistance,IGF2BP2: insulin growth factor $2 \mathrm{mRNA}$ binding protein 2. 


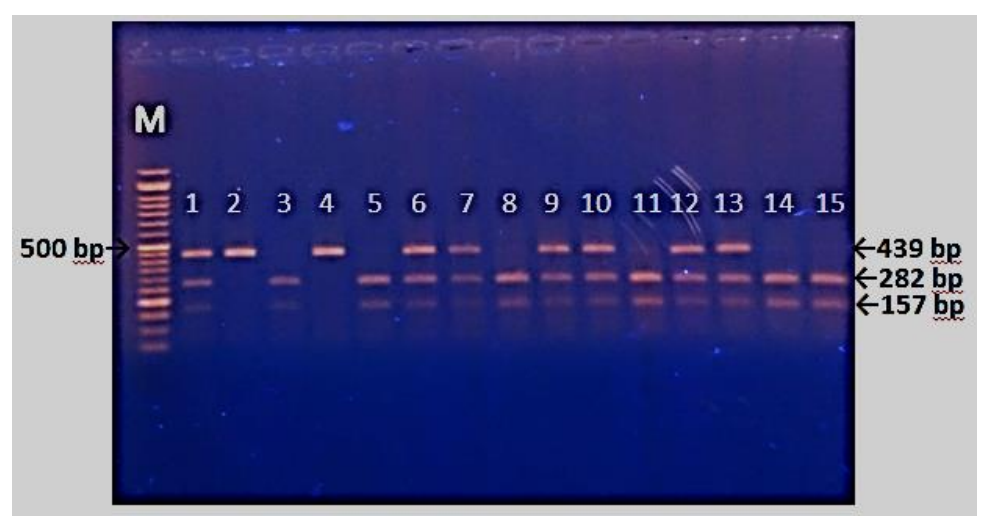

Figure 1. Agarose gel electrophoresis of restriction digests of PCR products of IGF2BP2 gene using MboII restriction enzyme on 2\%(w/v) agarose gel. M:50 bp Marker, lanes 3, 5 and 8 are GG genotypes, lanes 1, 6 and 7are GT genotypes and lanes 2 and 4 are TT genotypes for T2DM patients. Lanes11, 14 and 15 are GG genotypes, lanes 9,10,12 and 13 are GT genotypes for controls.

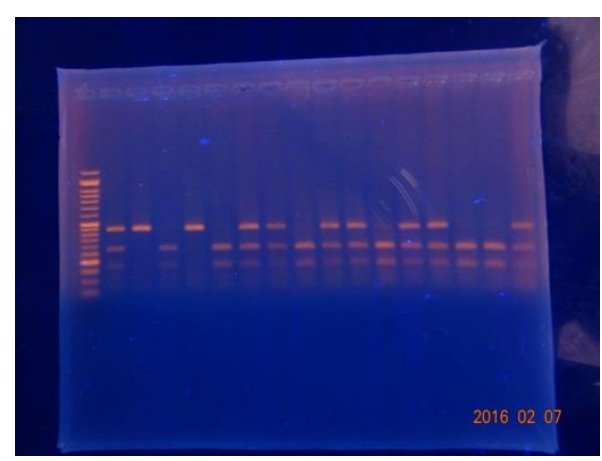

The original image

\section{DISCUSSION}

The IGF2BP2 is one of the genes identified through GWAS to be associated with T2DM, which has been repeatedly confirmed among different ethnic populations (Zeggini et al., 2007), many studies confirmed the association of (rs4402960) SNP of IGF2BP2 gene with T2DM, but other studies reported no association between this SNP 
and T2DM. Moreover, subsequent replication studies in different populations yielded inconsistent results.

Our results showed a strong association of IGF2BP2 SNP with T2DM under several genetic models. In previous study on Lebanese Arab population, IGF2BP2 gene variant (rs4402960) was associated with T2DM $\left(\mathrm{P}=6.5 \times 10^{-6}\right)$ under several genetic models with calculated OR values of 1.60 (Nemr et al., 2012). Also, for rs4402960 variant, significant association with T2DM was identified in Moroccan population under additive $(\mathrm{P}=0.009)$ and recessive $(\mathrm{P}=0.003)$ models with calculated OR value of 1.34 (Benrahma., 2014), and with T2DM $\left(\mathrm{OR}=1.86,95 \% \mathrm{CI}=1.34-2.58, \mathrm{P}<10^{-4}\right)$ in Tunisian population (Lasram et al., 2015). The results of the current study were in contrast to those reported by Ibrahim et al. (2016) who found that no association of (rs4402960) variant of IGF2BP2 gene with T2DM in Sudanese population.

Several large-scale population studies reported an association between the IGF2BP2 rs4402960 variant and T2DM in European populations such as Greek-Cypriot Population (Votsi et al., 2017), as well as in Asians such as Japanese (Iwata et al,. 2012) and Chinese (Rao et al., 2016). In contrast, other studies on Norwegians (Hertel et al., 2008), Indians (Kommoju et al., 2013) and Russian population (Chistiakov et al., 2012) did not detect the association of $I G F 2 B P 2$ variant (rs4402960) with T2DM.

The insignificant associations found in other ethnic populations could be explained by study design, sample size or the limited number of studies which had insufficient statistical power to detect a slight effect (Han et al., 2010). Also, some studies have examined several genetic models (Nemr et al., 2012), while other studies have examined only the additive model (Hertel et al., 2008).

The present study revealed that (GT+TT) genotypes of (rs4402960) variant of IGF2BP2 gene carriers of diabetic patients showed significantly higher fasting plasma glucose levels as compared with carriers of GG genotype. Zhang et al. (2014) reported that T2DM patients with the $\mathrm{T}$ allele had higher FPG $(\mathrm{P}<0.01)$ and $2-\mathrm{h}$ PPG $(\mathrm{P}<0.05)$ levels than those with the GG genotype.

In our study, the diabetic patients who carried (GT+TT) genotype of IGF2BP2 SNP (rs4402960) were associated with significant reduction of homeostatic model assessment of $\beta$-cell function (HOMA- $\beta \%$ ) compared with carriers of GG genotype. The association of this SNP 
with HOMA- $\beta$ reduction suggested that IGF2BP2 gene variant (rs4402960) confers T2DM risk through a reduction of $\beta$-cell function (Huang et al., 2010).

Our data revealed significant elevation of serum IGF2BP2 protein in diabetic patients compared to control subjects $(\mathrm{P}<0.05)$. The high level of IGF2BP2 protein suggested that up-regulation of IGF2BP2 in T2DM could influence insulin-like growth factor 2 (IGF2) levels, as IGF2BP2 binds to the $5^{\prime}$-UTR of the IGF2 mRNAs, influencing the protein levels (Dai et al., 2011). IGF2 overexpression in islets leads to islet dysfunction and makes them more vulnerable to $\beta$-cell damage and immune attack in mice (Casellas et al., 2015).

The exact biological role of IGF2BP2 in the pathogenesis of T2DM is not well elucidated, multiple studies have suggested that IGF2BP2 polymorphisms were associated with an impaired pancreatic $\beta$-cell function (Zeggini et al., 2007).

Interactions between genetic variation in IGF2BP2 and T2DM may be exerted through the IGF2 pathway and through the insulin pathway. In addition, IGF $2 B P 2$ has been demonstrated to affect first-phase insulin secretion and the disposition index during hyperglycemic clamps. It is possible that $I G F 2 B P 2$ would reduce the size or number of $\beta$-cells by sequestering IGF2 mRNA in these cells, resulting in a reduced insulin secretion (Rodriguez et al., 2010).

In conclusion, In this study, we validated that the IGF2BP2 polymorphism (rs4402960) may be associated with the development of T2DM and the IGF2BP2 may be a susceptibility gene for T2DM in Egyptian population resident in Ismailia city.

\title{
Acknowledgment:
}

The authors are indebted to the participants for their utmost cooperation.

\section{REFERENCES}

\begin{abstract}
American Diabetes Association. "2. Classification and diagnosis of diabetes." Diabetes Care 40.Supplement 1 (2017): S11-S24. Benrahma, H., Charoute, H., Lasram, K., Boulouiz, R., Atig, R.K.-B., Fakiri, M., et al. (2014). Association Analysis of IGF2BP2, KCNJ11, and CDKAL1 Polymorphisms with Type 2 Diabetes Mellitus in a Moroccan Population: A Case-Control Study and Metaanalysis. Biochemical Genetics, 52(9-10), 430-442.
\end{abstract}


Boudoukha, S., Cuvellier, S., \& Polesskaya, A. (2010). Role of the RNA-binding protein IMP-2 in muscle cell motility. Molecular and cellular biology, 30(24), 5710-5725.

Casellas, A., Mallol, C., Salavert, A., Jimenez, V., Garcia, M., Agudo, J., et al. (2015). Insulin-like growth factor 2 overexpression induces $\beta$-cell dysfunction and increases beta-cell susceptibility to damage. Journal of Biological Chemistry, 290(27), 16772-16785.

Chistiakov, D.A., Nikitin, A.G., Smetanina, S.A., Bel'chikova, L.N., Suplotova, L.A., Shestakova, M.V., et al. (2012). The rs11705701 G> A polymorphism of IGF2BP2 is associated with

IGF2BP2 mRNA and protein levels in the visceral adipose tissue-a link to type 2 diabetes susceptibility. The review of diabetic studies: RDS, 9(2-3), 112.

Dai, N., Rapley, J., Angel, M., Yanik, M.F., Blower, M.D., \& Avruch, J. (2011). mTOR phosphorylates IMP2 to promote IGF2 mRNA translation by the internal ribosomal entry. Genes \& development, 25(11), 1159-1172.

Ding, D., Chong, S., Jalaludin, B., Comino, E., \& Bauman, A.E. (2015). Risk factors of incident type 2-diabetes mellitus over a 3-year follow-up: Results from a large Australian sample. Diabetes research and clinical practice, 108(2), 306-315.

Hafner, M., Landthaler, M., Burger, L., Khorshid, M., Hausser, J., Berninger, P., et al. (2010). Transcriptome-wide identification of RNA-binding protein and microRNA target sites by PAR-CLIP. Cell, 141(1), 129-141.

Han, X., Luo, Y., Ren, Q., Zhang, X., Wang, F., Sun, X., et al. (2010). The implication of genetic variants near SLC30A8, HHEX, CDKAL1, CDKN2A/B, IGF2BP2, FTO, TCF2, KCNQ1, and WFS1 in type 2 diabetes in a Chinese population. BMC medical genetics, $11(1), 81$.

Hertel, J., Johansson, S., Raeder, H., Midthjell, K., Lyssenko, V., Groop, L., et al. (2008). Genetic analysis of recently identified type 2 diabetes loci in 1,638 unselected patients with type 2 diabetes and 1,858 control participants from a Norwegian population-based cohort (the HUNT study). Diabetologia, 51(6), 971.

Huang, Q., Yin, J.-y., Dai, X.-p., Pei, Q., Dong, M., Zhou, Z.-g., et al. (2010). IGF2BP2 variations influence repaglinide response and 
risk of type 2 diabetes in a Chinese population. Acta Pharmacologica Sinica, 31(6), 709.

Ibrahim, A.T., Hussain, A., Salih, M.A., Ibrahim, O.A., Jamieson, S.E., Ibrahim, M.E., et al. (2016). Candidate gene analysis supports a role for polymorphisms at TCF7L2 as risk factors for type 2 diabetes in Sudan. Journal of Diabetes \& Metabolic Disorders, 15(1), 4.

\section{IDF: International Diabetes Federation 2017; Diabetes Atlas 8th} Edition.

Iwata, M., Maeda, S., Kamura, Y., Takano, A., Kato, H., Murakami, S., et al. (2012). Genetic risk score constructed using 14 susceptibility alleles for type 2 diabetes is associated with the early onset of diabetes and may predict the future requirement of insulin injections among Japanese individuals. Diabetes Care, 35(8), 17631770 .

Kommoju, U.J., Maruda, J., Kadarkarai, S., Irgam, K., Kotla, J.P., Velaga, L., et al. (2013). No detectable association of IGF2BP2 and SLC30A8 genes with type 2 diabetes in the population of Hyderabad, India. Meta gene, 1, 15-23.

Lasram, K., Ben Halim, N., Benrahma, H., Mediene-Benchekor, S., Arfa, I., Hsouna, S., et al. (2015). The contribution of CDKAL1 rs7756992 and IGF2BP2 rs4402960 polymorphisms in type 2 diabetes, diabetic complications, obesity risk and hypertension in the Tunisian population. Journal of diabetes, 7(1), 102-113.

Li, Z., Zhang, Y., Ramanujan, K., Ma, Y., Kirsch, D.G., \& Glass, D.J. (2013). Oncogenic NRAS, Required for Pathogenesis of Embryonic Rhabdomyosarcoma, Relies upon the HMGA2-IGF2BP2 Pathway. Cancer research, 73(10), 3041-3050.

Matthews, D. R., Hosker, J. P., Rudenski, A. S., Naylor, B. A., Treacher, D. F., \& Turner, R. C. (1985). Homeostasis model assessment: insulin resistance and $\beta$-cell function from fasting plasma glucose and insulin concentrations in man. Diabetologia, 28(7), 412419.

National Cholesterol Education Program (NCEP) expert panel on detection, evaluation, and treatment of high blood cholesterol in adults (2002). Circulation; 106:3143-3151.

Nemr, R., Echtay, A., Dashti, E.A., Almawi, A.W., Al-Busaidi, A.S., Keleshian, S.H., et al. (2012). The strong association of common 
variants in the IGF2BP2 gene with type 2 diabetes in Lebanese Arabs. Diabetes research and clinical practice, 96(2), 225-229.

Rao, P., Wang, H., Fang, H., Gao, Q., Zhang, J., Song, M., et al. (2016). Association between IGF2BP2 Polymorphisms and Type 2 Diabetes Mellitus: A Case-Control Study and Meta-Analysis. International journal of environmental research and public health, 13(6), 574.

Rodriguez, S., Eiriksdottir, G., Gaunt, T., Harris, T., Launer, L., Gudnason, V., et al. (2010). IGF2BP1, IGF2BP2 and IGF2BP3 genotype, haplotype and genetic model studies in metabolic syndrome traits and diabetes. Growth Hormone \& IGF Research, 20(4), 310318.

Votsi, C., Toufexis, C., Michailidou, K., Antoniades, A., Skordis, N., Karaolis, M., et al. (2017). Type 2 Diabetes Susceptibility in the Greek-Cypriot Population: Replication of Associations with TCF7L2, FTO, HHEX, SLC30A8 and IGF2BP2 Polymorphisms. Genes, 8(1), 16.

Yamada, Y., Izawa, H., Ichihara, S., Takatsu, F., Ishihara, H., Hirayama, H., et al.. (2002). Prediction of the risk of myocardial infarction from polymorphisms in candidate genes. New England Journal of Medicine, 347(24), 1916-1923.

Ye, S., Song, W., Xu, X., Zhao, X., \& Yang, L. (2016). IGF2BP2 promotes colorectal cancer cell proliferation and survival through interfering with RAF-1 degradation by miR-195. FEBS letters, 590(11), 1641-1650.

Zeggini, E., Weedon, M.N., Lindgren, C.M., Frayling, T.M., Elliott, K.S., Lango, H., et al. (2007). Replication of genome-wide association signals in UK samples reveals risk loci for type 2 diabetes. Science, 316(5829), 1336-1341.

Zhang, L.-F., Pei, Q., Yang, G.-P., Zhao, Y.-C., Mu, Y.-F., Huang, Q., et al. (2014). The effect of IGF2BP2 gene polymorphisms on pioglitazone response in Chinese type 2 diabetes patients. Pharmacology, 94(3-4), 115-122. 


\section{الملخص العربي}

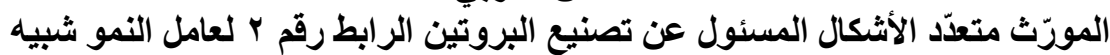

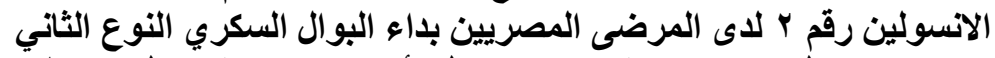

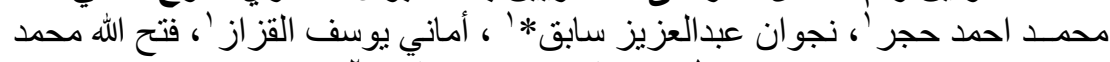

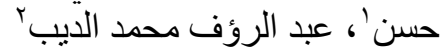

قسمى الكيمياء الحيوية الطبية و البيولوجيا الجزيئية ', الباطنة' ـ كلية الطب, جامعة قناة السويس الجز

يعرف داء البوال السكري من النوع الثاني بانه خلل مزمن في الايض (اضطر اب في في استقلاب

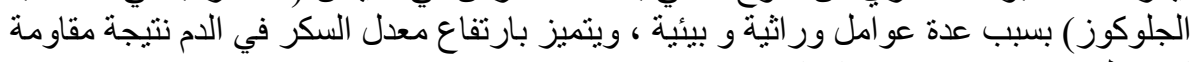

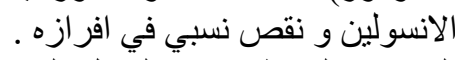

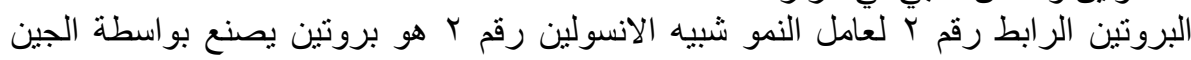

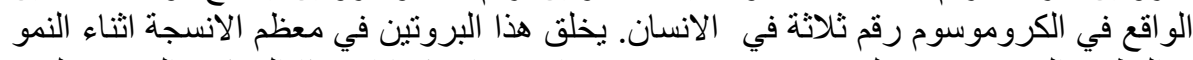

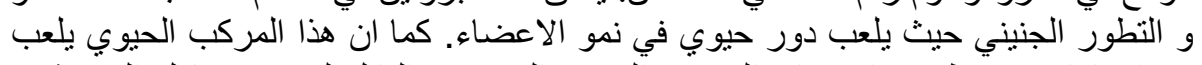

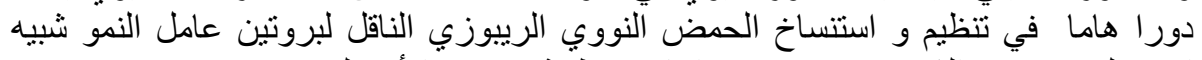

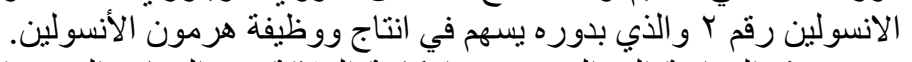

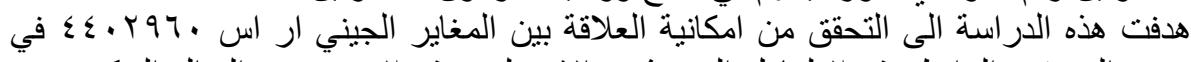

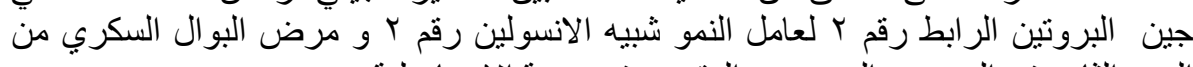

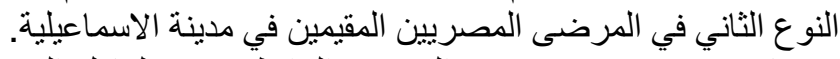

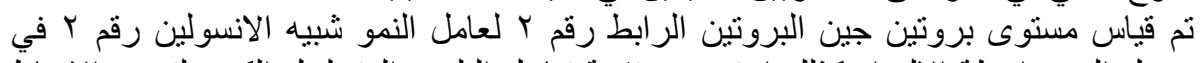

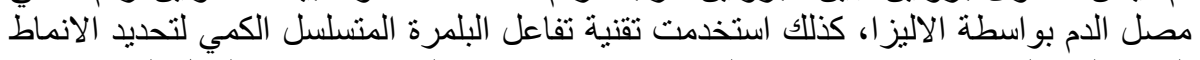

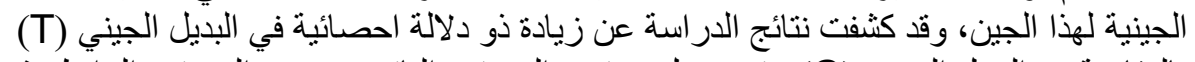

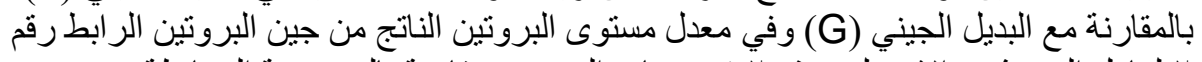

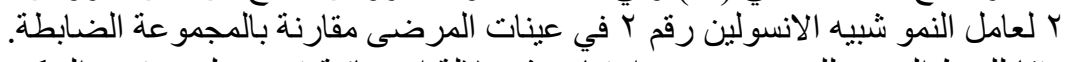

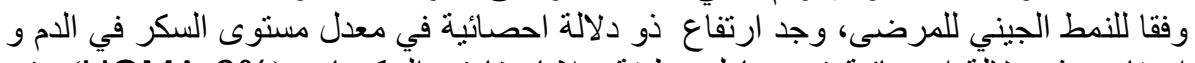

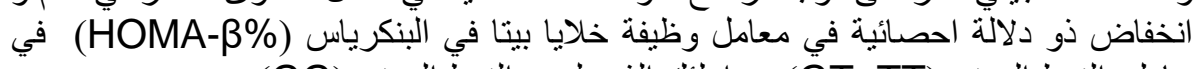

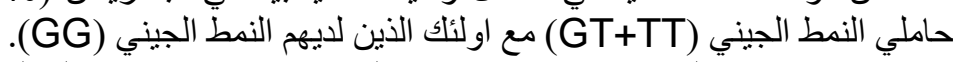

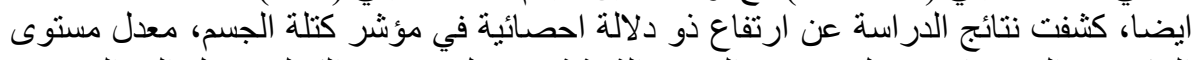

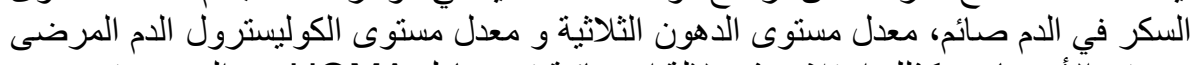

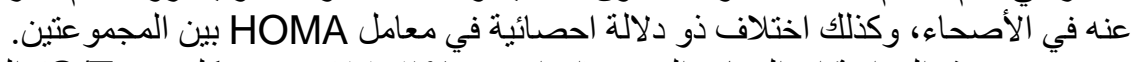

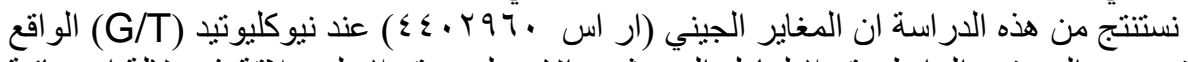

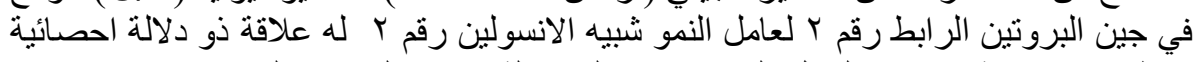

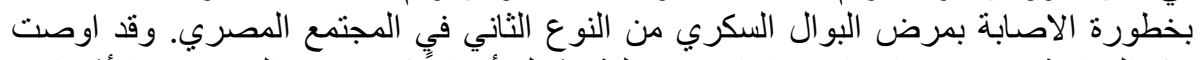

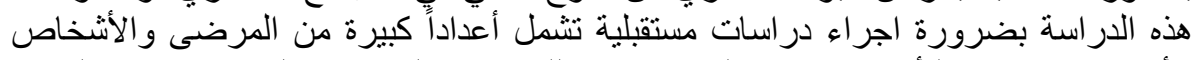

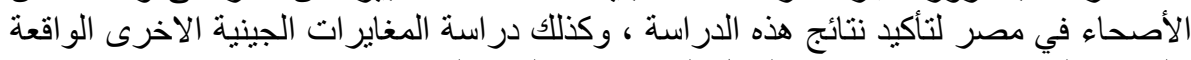
على هذا الجين و علاقتها بمرض البو البو ال السكري من النوع النو الثاني. 